J. Clin. Chem. Clin. Biochem.

Vol. 24, 1986, pp. 333-339

(C) 1986 Walter de Gruyter \& Co. Berlin - New York

\title{
Measurement of Fibronectin in Human Body Fluids
}

\author{
By Maria José Gómez-Lechón and J. V. Castell \\ Centro de Investigación, Hospital La Fe, Ministerio de Sanidad, Valencia, España
}

(Received July 30, 1985/January 2, 1986)

\begin{abstract}
Summary: Two facts must be taken into consideration when quantifying fibronectin in biological samples: the sensitivity of the assay method and the appropiate handling of samples. A three-antibody, non-competitive ELISA was used in the present study. This procedure offers a simple, inexpensive and very sensitive technique for evaluating fibronectin: reproducible standard curves in the range $5-100 \mu \mathrm{g} / 1,3 \%$ variability in the assay, and a detection limit of $0.5 \mathrm{ng} /$ well that allows accurate measurement of fibronectin in segmental bronchoalveolar lavage and in ascites liquid samples. Typical dilution ranged from $1 / 10000$ for plasma to 1/100 for bronchoalveolar lavages. For long-term storage of samples two procedures are recommended. First, a rapid freezing with liquid nitrogen, storage at $-20^{\circ} \mathrm{C}$ and thawing once at $37^{\circ} \mathrm{C}$ avoiding refreezing. Losses of immunoreactive fibronectin after 35 days storage were 15,15 and $22 \%$ in plasma, bronchoalveolar lavages and ascites fluid, respectively. Alternatively, samples can be stored as ammonium sulphate precipitates. This allows the easy availability of the samples when assays have to be repeated, and avoids fractionation in vials and freeze-thawing cycles. Using this storage procedure, losses are, however, slightly higher $(22,25,25 \%$, respectively, after 35 days).
\end{abstract}

\section{Bestimmung von Fibronectin in menschlichen Körperflüssigkeiten}

Zusammenfassung: Zwei Tatsachen müssen bei der Bestimmung von Fibronectin in biologischen Flüssigkeiten in Betracht gezogen werden: Die Empfindlichkeit der Bestimmungṣmethode und die angemessene Handhabung der Proben. Ein drei Antikörper verwendender, nicht-kompetitiver ELISA wurde in der vorliegenden Studie verwendet. Dieses Verfahren bietet eine einfache, billige und sehr empfindliche Technik für die Fibronectinbestimmung: reproduzierbare Standardkurven im Bereich von 5-100 $\mu \mathrm{g} / \mathrm{l}$, eine Impräzision von $3 \%$ und eine Nachweisgrenze von 0,5 ng im Ansatz, was eine genaue Messung von Fibronectin in Proben von Ascitesflüssigkeit und bronchoalveolärer Waschflüssigkeit aus Lungensegmenten erlaubt. Die typische Verdünnung lag zwischen 1/10000 für Plasma und 1/100 für bronchoalveoläre Waschflüssigkeit. Für die Langzeitaufbewahrung von Proben werden zwei Verfahren empfohlen: 1. Schnelles Einfrieren mit flüssigem Stickstoff, Aufbewahrung bei $-20^{\circ} \mathrm{C}$ und einmaliges Auftauen bei $37^{\circ} \mathrm{C}$, Vermeidung von erneutem Einfrieren. Die Verluste von immunreaktivem Fibronectin nach 35 Tagen Lagerung betrugen hier 15, 15 bzw. 22\% in Plasma, bronchoalveolärer Wạschflüssigkeit bzw. Ascites; 2. Aufbewahrung der Proben als AmmoniumsulfatPräzipitate; das erlaubt die einfache Verfügbarkeit der Proben, wenn Bestimmungen wiederholt werden müssen, und vermeidet die Verteilung auf Probenbehälter sowie wiederholtes Einfrieren und Auftauen. Bei Verwendung dieser Lagerungsmethode sind die Verluste jedoch etwas höher (22, 25, 25\% nach 35 Tagen).

\section{Introduction}

Fibronectin is a multifunctional and polymorphic glycoprotein found in two forms in living organisms: as a large insoluble aggregate that interacts strongly with other extracellular matrix components, and as a soluble form, present in plasma and other biological fluids $(1,2)$. The protein mediates several functions, namely, cell attachment and spreading $(3,4)$, cellular 
morphology (5), wound healing processes $(6,7)$, nonimmune opsonization $(8-10)$ and aging of tissues (11). Since fibronectin is involved in many important biological activities, its levels may have a potential clinical value $(12-21)$.

Two facts must be considered when quantifying fibronectin in biological fluids. First, the characteristics of a particular method; second, the correct handling of the samples to be evaluated. Concerning the first point, there have been reports on several methods used to quantify soluble fibronectin. These methods are based either on electroimmunoassays (22), immunological precipitation (10), or turbidimetric methods, i. e. laser nephelometry (23), radioimmunoassay (24), or competitive ELISA (25). Among the described methods RIA is presumably the only one with sufficient sensitivity to evaluate fibronectin in biological fluids with low fibronectin contents. This requires the use of radiactive tracers which in the case of fibronectin, is problematic (24). We developed (26) a sensitive three-step non-competitive ELISA to quantify animal fibronectins, which we have now adapted for evaluating small amounts of fibronectin in clinical samples.

The second factor of interest is that fibronectin is a "sticks-to-all" protein, and its handling in the clinical laboratory is critical. Significant losses of protein are frequent during isolation and storage of samples. Both factors are important in the evaluation of fibronectin in biological samples, and the existence of contradictory data is probably directly related to those two facts.

The aim of this study was to investigate the conditions for sample collection and storage for the measurement of fibronectin by ELISA in human biological fluids.

\section{Materials and Methods}

\section{Reagents}

2,2'-Azino-di-(3-ethyl-benzthiazoline sulphonic acid (6)) (ABTS) was from Sigma. Horseradish peroxidase (EC 1.11.1.7) was from Boehringer Mannheim. Heparin was from Rovi S. A. (Madrid, Spain). Tween-20 was from Merck, (art. No 822184). Crystalline polystyrene microtiter plates for ÉLISA were M-29 from Greiner. All other chemicals were of analytical grade.

\section{Collection and storage of biological samples}

Blood was drawn from healthy fasted individuals $(n=40)$ by puncturing the radial vein. Three anticoagulants were used: heparin, $25 \mathrm{IU} / \mathrm{ml}$; trisodium citrate, $11 \mathrm{mmol} / \mathrm{l}$; or EDTA, 62 $\mathrm{mmol} / \mathrm{l}$. Plasma was separated by centrifuging the blood, 10 $\min$ at $1500 \mathrm{~g}$ at room temperature. Serum was obtained after allowing blood to coagulate for 4 hours at room temperature and centrifuging the clot $10 \mathrm{~min}$ at $1500 \mathrm{~g}$.
Segmental bronchoalveolar lavage was performed in 10 individuals who were in good health and showed no symptoms of respiratory disorders. The bronchoscope was wedged in a subsegment of a lobe and $100 \mathrm{ml}$ of warm sterile saline was instilled in several portions and recovered by gentle aspiration. The samples were put on ice and filtered through two layers of surgical gauze, centrifuged to remove cells $(20 \mathrm{~min}$ at $500 \mathrm{~g})$ and stored as indicated below.

Ascites liquid was obtained from patients having ascites by intraperitoneal puncture and transferred to containers for further storage.

Aliquots of each sample were simultaneously kept under different conditions:

a) in the cold at $4{ }^{\circ} \mathrm{C}$ with merthiolate $0.1 \mathrm{mg} / 1$ or azide $0.2 \mathrm{~g} / 1$ as preservative;

b) rapidly frozen (liquid $\mathrm{N}_{2}$ ) and stored at $-20^{\circ} \mathrm{C}$;

c) precipitated with ammonium sulphate at 0.50 saturation;

d) adsorbed onto micro ELISA plates and stored in the cold.

Frozen samples were thawed at $37^{\circ} \mathrm{C}$.

Preparation of fibronectin standards and fibronectin-free albumin

Human fibronectin was prepared by affinity chromatography as described (26) and stored in $2 \mathrm{~mol} / 1$ urea, $1 \mathrm{~mol} / 1 \mathrm{NaCl}$ at $-20^{\circ} \mathrm{C}$. When the stock solution of fibronectin was examined using SDS polyacrylamide electrophoresis in the presence of mercaptoethanol, it showed a single doublet $\left(M_{\mathrm{r}} 215000\right.$ and 220000 ), as described (18). Under these conditions no significant losses or degradation of fibronectin were observed after one year. Fibronectin concentration was estimated either by Lowry's method or by laser densitometry (LKB ULtroscan 2202) as described (26). Fibronectin-free albumin was obtained as described (26).

\section{Antisera}

Sheep anti human fibronectin was produced in our laboratory following conventional immunization schedules, although the commercially available Boehringer antisera was equally suitable for this assay. Rabbit anti sheep IgG's were obtained by immunizing rabbits with pure sheep IgG's. Goat anti rabbit IgG was obtained and tested as described (26). Rabbit IgG's anti-sheep IgG's were routinely immunoadsorbed against whole human sera prepared by insolubilization of human plasma with $10 \%$ formaldehyde. The IgG fraction of goat anti rabbit IgG was labelled with horseradish peroxidase according to the twostep procedure of Nakane \& Kanewi (29) and assayed for its suitability for use in ELISA.

\section{ELISA procedure}

All assays were run as triplicates of two independent dilutions.

1) Fibronectin standards and tests were conveniently diluted in buffer $\mathrm{A}$ (sodium carbonate buffer $50 \mathrm{mmol} / \mathrm{l}, \mathrm{pH}$ 9.6) containing $60 \mathrm{mg} / \mathrm{l}$ of fibronectin-free albumin. Plasma dilution was $1 / 6000$ to $1 / 10000 ; 1 / 50$ to $1 / 100$ for segmental bronchoalveolar lavage and $1 / 1000$ to $1 / 2000$ for ascites liquid. Diluted samples $(100 \mu \mathrm{l})$ were allowed to adsorb for $30 \mathrm{~min}$ at $37^{\circ} \mathrm{C}$ in a humid incubator.

2) The antigen excess was poured off and the plates were washed with buffer B ( $200 \mathrm{mmol} / 1$ phosphate buffer $\mathrm{pH} 7,9 \mathrm{~g} / \mathrm{l}$ $\mathrm{NaCl}, 1 \mathrm{ml} / 1$ Tween-20). At this stage the plates were emptied and, if not used immediately, they were stored at $4^{\circ} \mathrm{C}$ without measurable loss of antigenicity. Ten dáys was the longest storage period tested. 
3) A volume of $100 \mu$ l of sheep anti-human fibronectin $1 / 6000$ in buffer B was added to the wells and incubated at $37^{\circ} \mathrm{C}$ for 1 hour. Each sample had its own blank well where the first antiserum was non-immune sheep IgG. After washing with buffer $\mathrm{B}$, wells were again incubated for $30 \mathrm{~min}$ at $37^{\circ} \mathrm{C}$ with $100 \mu \mathrm{l}$ of 1/2000 rabbit anti-sheep IgG diluted in buffer B.

4) Wells were incubated with peroxidase-labelled conjugate $(1 / 8000)$ for $30 \mathrm{~min}$ at $37^{\circ} \mathrm{C}$. Thereafter the plates were washed and $100 \mu \mathrm{l}$ of $0.2 \mathrm{mmol} / \mathrm{l} \mathrm{ABTS}, 2 \mathrm{mmol} / 1 \mathrm{H}_{2} \mathrm{O}_{2}$ in citrate buffer $0.1 \mathrm{~mol} / 1 \mathrm{pH} 4.2$ were added. The enzyme acitivty was measured after incubation at $37^{\circ} \mathrm{C}$ in a micro ELISA reader (MR 600 Dynatech Lab. Inc.) at $405 \mathrm{~nm}$.

\section{Results}

Collection of samples for fibronectin determination

We undertook a series of experiments to establish the conditions necessary to assure reproducible values of fibronectin. In blood, fibronectin was estimated either in serum or in the plasma of the same blood sample treated with different anticoagulants. The measured fibronectin content of serum was $19.66 \% \pm 5.58$ $(n=40)$ lower than that of citrated plasma. No significant differences were found between citrated and EDTA plasma (less than $2 \%$ ), but the values for heparinized plasma were significantly lower $(13.21 \%$ $\pm 4.63 ; n=40)$. According to our experience, plastic tubes are not appropiate sample containers since fibronectin is known to firmly attach to plastic surfaces (26). Losses of $5-10 \%$ are to be expected due to this factor. The effect is even greater in samples containing low amounts of fibronectin like segmental bronchoalveolar lavage. Fibronectin losses were negligible when standard borosilicate glass containers were used.

\section{Storage of samples}

A critical factor affecting the reproducibility of measurements was the storage of samples. Since for practical reasons the measurement of fibronectin was not usually performed on the day of sampling, we investigated the effects that conventional storage procedures could have on the fibronectin content of samples. Aliquots of plasma, ascites liquid and segmental bronchoalveolar lavage were stored under different conditions and their fibronectin content was measured during 35 days. At the indicated dates the samples were titrated and their relative fibronectin content calculated in relation to their initial content. As figure 1 a summarizes, there is a gradual loss of fibronectin in frozen and in precipitated $(2.1 \mathrm{~mol} / 1$ ammonium sulphate) plasma samples, decreasing to $80 \%$ of the initial content by day 35 . However in samples stored in the cold, their content quickly dropped below $50 \%$ of the initial values.

Fibronectin losses in segmental bronchoalveolar lavage and in ascites liquid were very great in samples stored in the cold. Their fibronectin content became undetectable by day 10 . In frozen and in precipitated samples the values after 35 days were $75-85 \%$ of initial values in segmental bronchoalveolar lavage (fig. $1 \mathrm{a}$ ) and $75-80 \%$ in ascites fluid (fig. $1 \mathrm{c}$ ). The

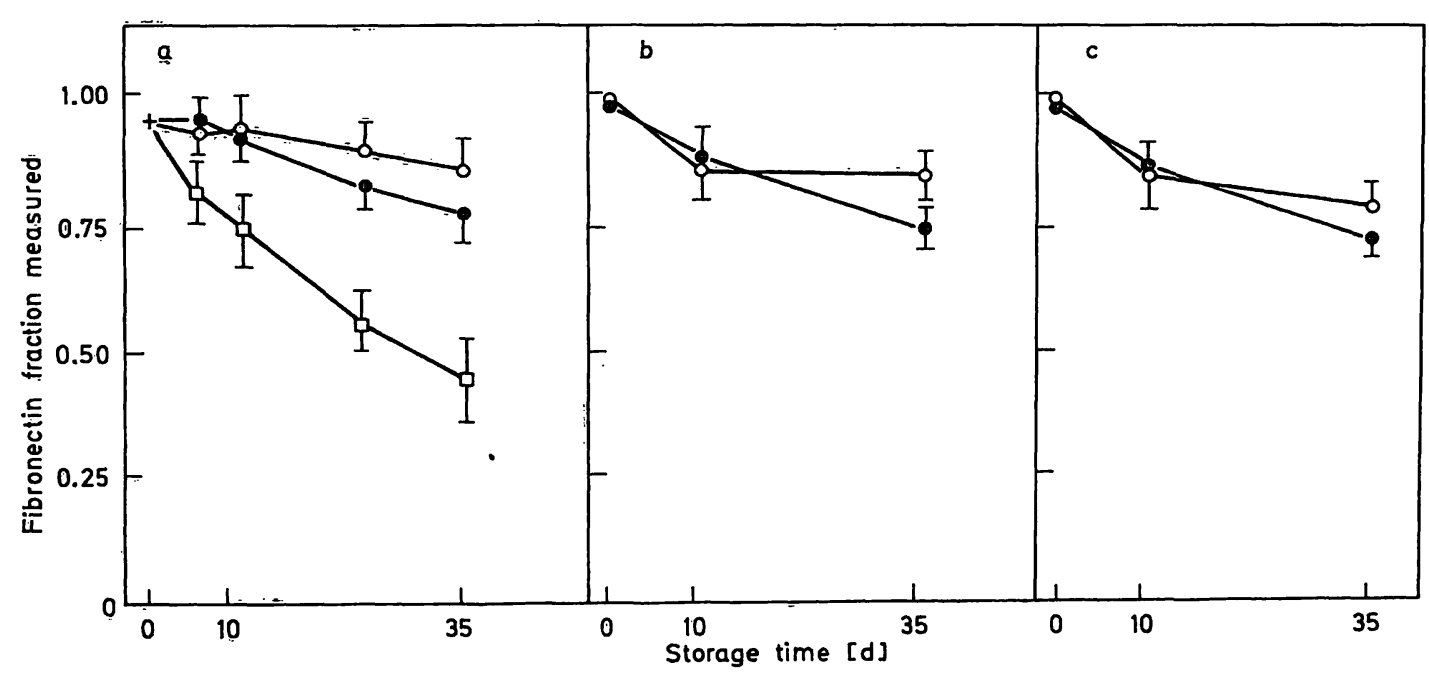

Fig. 1. Measurable fibronectin after long-term storage of plasma samples, segmental bronchoalveolar lavages and ascites Samples of citrated plasma $(a, n=40)$, bronchoalveolar lavage fluids $(b, n=10)$ or ascites fluid $(c, n=10)$, were distributed in aliquots which were stored under various conditions:

1) freezing in liquid nitrogen and storage at $-20^{\circ} \mathrm{C}(0)$,

2) precipitated with 0.50 saturation with ammonium sulphate (a), and

3) storage in the cold in presence of antimicrobials (๑).

At different days samples were assayed for their fibronectin content, and the value was expressed as a fraction of the content at day 0 . The values in the figure represent the mean $\pm S$. D. ( $p$ for all points $\leqslant 0.005$ ). 
losses of fibronectin in frozen samples after thawing was also studied. The results showed that if samples needed to be frozen, they should always be thawed in a water bath at $37^{\circ} \mathrm{C}$. When thawing at room temperature, we found a reduction of up to $20 \%$ of the initial fibronectin content. Repeated freezingthawing, even with thawing at $37^{\circ} \mathrm{C}$, greatly reduced the fibronectin content $(50 \%$ after 5-cycles of freezing-thawing), and therefore should be avoided.

In a third experiment, ELISA plates were coated with the human sample the day they arrived at the laboratory, then washed, stored in the cold, but not taken through the rest of the steps of ELISA until several days later. In relation to their initial fibronectin content, plates coated with plasma samples $(\mathrm{n}=10)$ on day 0 and processed on day 10 lost only $2.7 \pm 2.2 \%$ of their immunoreactive fibronectin, which was not statistically significant, whereas the same samples, stored at $-20^{\circ} \mathrm{C}$ during this period, assayed on day 10 , lost $4.1 \pm 1.3 \%$.

\section{Titration curve: Sensitivity and precision}

To measure fibronectin concentrations in samples the values of absorbance of fibronectin standards were plotted in a semilog paper against the concentration of fibronectin, and the linear regression of absorbance against the $\log$ of concentration of fibronectin was calculated. Excellent correlations were obtained in the range of $0.5-10 \mathrm{ng}$ of fibronectin per well $(r=0.99)$. To assess the inter-assay reproducibility of the data, several calibration curves were made with fibronectin standards. Figure 2 shows the mean \pm standard deviation of six calibration lines each made on a different day. The low deviation of values clearly shows the high reproducibility of this assay.

Fibronectin measurement in human plasma, ascites and segmental bronchoalveolar lavage

To assess the internal accuracy of this method for measuring fibronectin in human plasma, we performed the following experiment: we first prepared standards of known concentrations of fibronectin made up by diluting the appropiate amount of fibronectin in fibronectin-free albumin. The same amounts of fibronectin were added to a previously defibronectized human plasma. These plasma standards were processed and assayed at two different dilutions $(1 / 4000$ and $1 / 6000)$ by ELISA to estimate their fibronectin content. The results obtained are represented in figure 3. There is a small underestimate of fibronectin content in plasma in relation to pure fibronectin standards, which is slightly greater when plasma is assayed at a dilution 1/4000 instead of a dilution $1 / 6000$. To assess intra-assay specificity and reproducibility, we measured a patient's plasma sample 10 times, making a new dilution each time and doing triplicate assays for each dilution. The variability in the absorbance readings were quite low $(0.572$ $\pm 0.017, \mathrm{n}=30,3 \%$ error). The limit of sensitivity of the technique was estimated by determining the

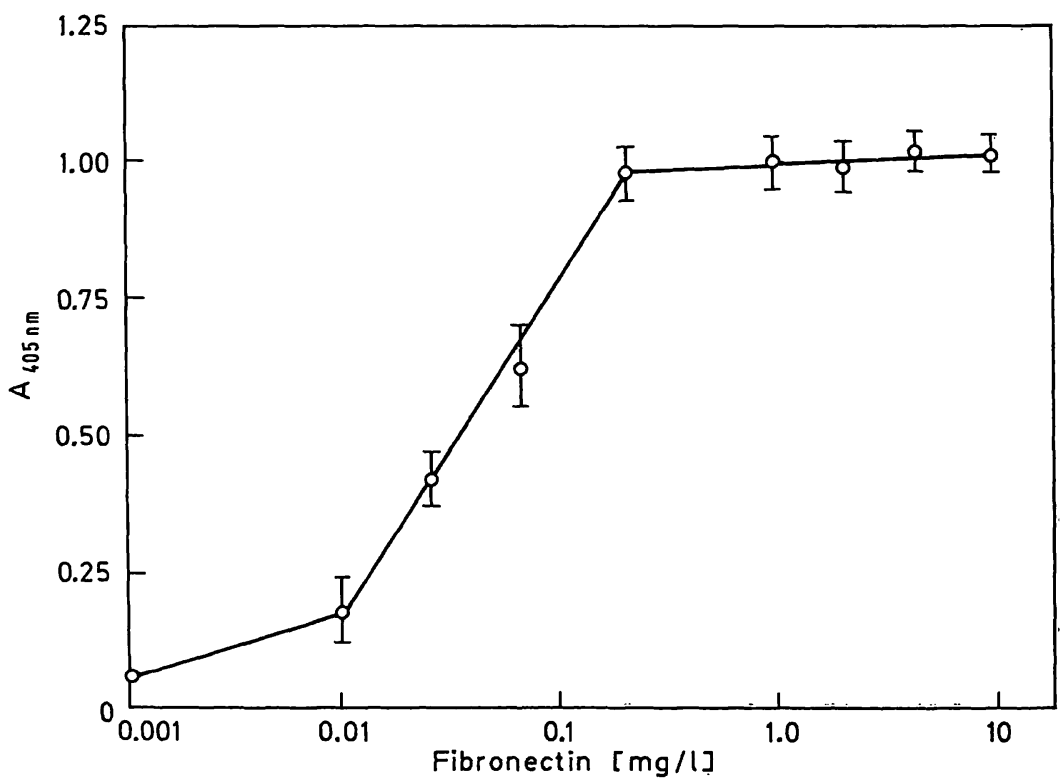

Fig. 2. Non-competitive, indirect ELISA for fibronectin measurement, standard curve

Samples of $100 \mu \mathrm{l}$ in buffer A containing variable amounts of fibronectin were allowed to adsorb onto the plastic of a microtiter plate. After washing and completing the steps of the ELISA, as reported in Materials and Methods, the final colour absorbance was plotted against the fibronectin content of the samples. Values denoterthe mean $\pm S$. D. of six different curves made at different days. 


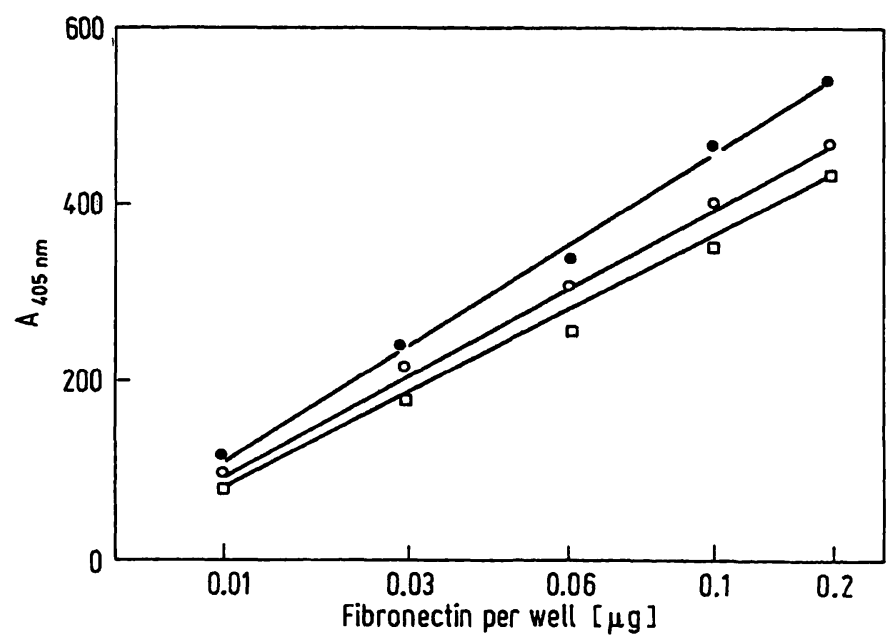

Fig. 3. Titration curves for fibronectin

To assess the linearity and reproducibility of the method for quantifying plasma fibronectin, increasing known amounts of fibronectin were diluted in buffer A containing $60 \mathrm{mg} / \mathrm{l}$ of fibronectin-free albumin ( $(\bullet)$, or added to human plasma that had been previously de-fibronectinized. These were handled as routine samples, and their fibronectin content was measured by ELISA. The plasma was assayed at two different dilutions, $1 / 4000$ (口) and $1 / 6000(0)$. The results represent the colour absorbance after completing the ELISA in relation to the fibronectin present in samples.

smallest amount of fibronectin which gave an absorbance value significantly different from the blank. We used the t-test and analysed 20 negative controls and 20 positive samples. The lowest measurable concentration with this assay was $5 \mu \mathrm{g} / 1(0.5 \mathrm{ng} /$ well $)$, $\mathrm{p} \leqslant 0.01$.

We also studied the effects of dysproteinaemia and hyperlipaemia on the accuracy of the method. To evaluate possible interference from variable concentrations of total protein in individual samples, binding of fibronectin to the microplate was studied using a constant fibronectin concentration $(250 \mu \mathrm{g} / \mathrm{l})$ and variable amounts of fibronectin-free albumin as ex- ternal protein source $(0-10 \mathrm{mg} / \mathrm{l})$. The results showed no appreciable effects on the accuracy of fibronectin estimation over a wide range of external protein concentrations. The protein present in plasma samples at the dilution used in the assay $(1 / 6000-1 / 10000,1-0.6 \mu \mathrm{g} /$ well $)$ did not interfere with the binding of fibronectin.

The possible effects of lipids on the estimates of plasma fibronectin were followed in 10 healthy human fasted volunteers. Blood was obtained and each volunteer received $150 \mathrm{ml}$ of double-cream strawberry shake. After $120 \mathrm{~min}$ a blood sample was obtained and cholesterol, triacylglycerol and fibronectin were measured before and after the ingestion. The results presented in table 1 show that induced hyperlipaemia did not interfere with the fibronectin estimate in spite of the great variations in plasma lipids. Subject 9 had $1780 \mathrm{mg} / 1$ triacylglycerol before the experiment and $4220 \mathrm{mg} / \mathrm{l}$ afterwards, i. e. a $58 \%$ increase. However, fibronectin only varied by $+3 \%$. In another case the effect was opposite; in subject 2 , triacylglycerol before the experiment was $1040 \mathrm{mg} / \mathrm{l}$, and afterwards it was $2000 \mathrm{mg} / \mathrm{l}$, i. e. a $48 \%$ increase; fibronectin varied by $-6 \%$. In others, (subject 1, triacylglycerol before: $1100 \mathrm{mg} / \mathrm{l}$, after: $1860 \mathrm{mg} / \mathrm{l}$; an increase of $41 \%$ ) fibronectin did not change significantly $(-0.01 \%)$. The mean of the variations is not significant and falls within the error of the method.

We also compared the results obtained with this procedure with literature values (tab. 2). Plasma of 40 healthy individuals, 10 healthy segmental bronchoalveolar lavages and 35 ascites of hepatic cirrhosis were studied. This ELISA, because of its sensitivity, could be used to evaluate fibronectin in segmental bronchoalveolar lavage and in ascites liquid.

Tab 1. The effect of hyperlipaemia on the estimate of plasma fibronectin.

\begin{tabular}{|c|c|c|c|c|c|c|}
\hline Subject & \multicolumn{2}{|c|}{$\frac{\text { Fn*) after }=\text { Fn*) before }}{\left.\text { Fn }^{*}\right) \text { before }} \%$} & \multicolumn{2}{|c|}{$\begin{array}{l}\text { Cholesterol }(\mathrm{mg} / \mathrm{l}) \\
\text { before after } \\
\text { lipid ingestion }\end{array}$} & \multicolumn{2}{|c|}{$\begin{array}{l}\text { Triacylglycerol (mg/l) } \\
\text { before after }\end{array}$} \\
\hline $\begin{array}{rr}1 & \\
2 & \\
3 & \\
4 & \\
5 & \\
6 & \\
7 & \\
8 & \\
9 & \\
10 & \end{array}$ & $\begin{array}{ll}+0.01 & \mathrm{~ns} \\
-6 & \mathrm{~ns} \\
+5 & \mathrm{~ns} \\
-6 & \mathrm{~ns} \\
+3 & \mathrm{~ns} \\
+5 & \mathrm{~ns} \\
+1.5 & \mathrm{~ns} \\
-8 & \text { ns } \\
+3 & \text { ns } \\
-7 & \text { ns }\end{array}$ & ' & $\begin{array}{l}2300 \\
2060 \\
1940 \\
2040 \\
2940 \\
1420 \\
2220 \\
2530 \\
2740 \\
1440\end{array}$ & $\begin{array}{l}2640 \mathrm{~ns} \\
1990 \mathrm{~ns} \\
1900 \mathrm{~ns} \\
2030 \mathrm{~ns} \\
2500 \mathrm{~ns} \\
1630 \mathrm{~ns} \\
2190 \mathrm{~ns} \\
2750 \mathrm{~ns} \\
2700 \mathrm{~ns} \\
1430 \mathrm{~ns}\end{array}$ & $\begin{array}{r}1100 \\
1040 \\
860 \\
1120 \\
1160 \\
700 \\
1200 \\
1260 \\
1780 \\
820\end{array}$ & $\begin{array}{l}1860 \\
2000 \\
1500 \\
2020 \\
2740 \\
1620 \\
2360 \\
2040 \\
4220 \\
1800\end{array}$ \\
\hline
\end{tabular}

*) $\mathrm{Fn}=$ fibronectin

Cholesterol, triacylglycerol (chylomicrons) and fibronectin were measured in the plasma of 10 healthy fasted volunteers before and 120 minutes after ingestion of $150 \mathrm{ml}$ of double-cream. Fibronectin results are expressed as mean variation of the independent determinations, each one in triplicate, and analysed by the Student's t-test. ns = no significative 
Tab. 2. Fibronectin measurement in biological samples.

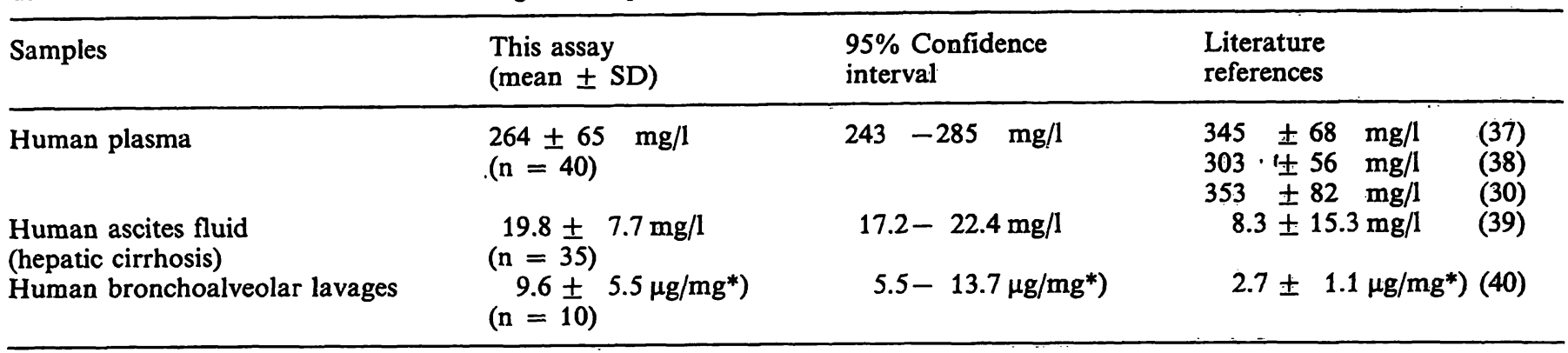

*) $\mu \mathrm{g}$ of fibronectin per $\mathrm{mg}$ of total protein in the sample.

\section{Discussion}

Sample collection is one of the factors influencing the quality of the data. There is significantly less fibronectin in serum than in plasma, because variable amounts of fibronectin are cross-linked to the fibrin by factor XIII during coagulation (30). We confirmed the results of Bowen et al. in the sense that citrate and EDTA gave the best results. Although plastic tubes have been recommended for plasma collection (31), our own experience and that recently pointed out by other authors (32) indicate that it should be avoided and that standard borosilicate tubes must be used.

The storage of samples also plays an important role. Fibronectin, formerly known as "cold insoluble globulin" $(1,27)$, precipitates in the cold together with fibrinogen and fibrinopeptides (33). Some authors reported that it could be stored at $4{ }^{\circ} \mathrm{C}$ for short periods (32). However, in our experience this procedure is not recommendable since very important losses occurred. We have alternatively assayed three different procedures:

1) freezing in $\mathrm{N}_{2}$ and storage at $-20^{\circ} \mathrm{C}$;

2) precipitation with $2.1 \mathrm{~mol} / 1$ ammonium sulphate and

3) adsorption onto micro ELISA plates and storage in the cold.

The storage of samples as an ammonium sulphate precipitate was of practical use in samples containing large amounts of protein. It gives a fine and homogeneous precipitate that can be easily resuspended, and in which fibronectin remains well preserved. In low protein-content precipitated samples the losses of fibronectin are larger. The adsorption of samples onto plates for later estimates of fibronectin also gave results that did not differ from those obtained with frozen samples. Thawing is also critical and should be performed at $37^{\circ} \mathrm{C}$. Samples should not be refrozen. This contrasts with previous reports $(30)$ and should be considered if the sample has to be re- assayed. Under optimal conditions $\left(-20^{\circ} \mathrm{C}\right)$, plasma samples lost only $15 \%$ of their initial fibronectin content after 35 days. The loss in ammonium sulphate precipitated samples was only slightly greater than in frozen samples (fig. $1 \mathrm{a}$ ). This disadvantage was counteracted by the simplicity of the precipitation procedure, the ease of transport and the possibility of taking several aliquots without having to thaw a vial each time.

In segmental bronchoalveolar lavage and in ascites fluid, losses of fibronectin in samples stored in the cold were so great that only the other two procedures could be considered. Losses are similar to those found in plasma samples (fig. $1 \mathrm{~b}, \mathrm{c}$ ). In both cases frozen samples retained higher amounts of immunoreactive fibronectin. However, the simplicity of the ammonium sulphate precipitation often made it the most recommendable procedure for the storage and transport of samples from the hospital to this laboratory. Among several procedures tested for long-term storage of fibronectin standards, the best results were obtained when fibronectin was frozen $\left(-20^{\circ} \mathrm{C}\right)$ in $2 \mathrm{~mol} / 1 \mathrm{urea}, 1 \mathrm{~mol} / 1 \mathrm{NaCl}$. We found no degradation or protein losses after one-year storage (data not shown).

The ELISA we used in this work is linear in the range of $5-10 \mu \mathrm{g} / 1$ and has a limit of detection of $5 \mu \mathrm{g} / 1$, which is comparable to $1 \mu \mathrm{g} / 1$ reported for RIA (24, 35 ), and hundreds of times more sensitive than other reported immunological methods $(17,32,36,37)$; it thus allows the easy measurement of fibronectin in ascites and segmental bronchoalveolar lavage. Intraassay error is less than $3 \%$ when care is taken during pipetting and diluting of samples. The small differences $(10-15 \%)$ in the fibronectin content of plasma samples when values are calculated against either a pure fibronectin standard curve or a plasma standard curve, (fig. 3) are due to the short incubation times. used in the assay ( $30 \mathrm{~min}$ ), which do not allow $100 \%$ adsorption of fibronectin (26) and are minimized when adsorption of samples is prolonged för several hours. 
Changes in the protein content of plasma have no effect on the accuracy of estimates, since samples are diluted in fibronectin-free albumin at a final concentration of $6 \mu \mathrm{g} / \mathrm{well}$ and the plasma sample only contributes 0.6 to $1 \mu \mathrm{g} /$ well. In plasma with a lower protein concentration this contribution may be lower and, therefore, according to previous results (26), the absorption of fibronectin to plastic will be the same. The presence of triacylglycerol and cholesterol (chylomicrons) did not appreciably interfere with the fibronectin estimate. The experiment summarized in table 1 analysed 10 cases and, although the lipid variation in each individual before and after the ingestion of cream varied greatly, the fibronectin content did not change during the experiment.

The values we obtained in plasma are in agreement with those previously reported and assayed by other

\section{References}

1. Ruoslahti, E., Pierschbacher, M., Mayman, E. G. \& Engvall, E. (1982) Trends Biol. Sci. 7, 188-190.

2. Ruoslahti, E. \& Vaheri, J. (1975) J. Exp. Med. 141, 497-501.

3. Grinnell, F. (1978) Int. Rev. Cytol. 53, 65-144.

4. Gómez-Lechón, M. J. \& Castell, J. V. (1983) Cienc. Biol. $8,49-56$.

5. Yamada, K. M. \& Kennedy, D. W. (1979) J. Cell Biol. 80, $492-498$.

6. Grinnell, F. \& Feld, M. (1981) J. Biomed. Mat. Res. 15, $363-381$.

7. Donaldson, D. J. \& Mahan, J. T. (1983) J. Cell Sci. 62 , 117-127.

8. Villiger, B., Kelley, D. G., Engeleman, W., Kulh III Ch. \& McDonald, J. A. (1981) J. Cell Biol. 90, 711-720.

9. Lanser, K. F. \& Saba, T. M. (1982) Ann. Surg. 195, $340-345$.

10. Blumenstock, F., Weber̂, P. \& Saba, T. M. (1977) J. Biol. Chem. 252, 7156-7183

11. Aizawa, S., Mitsui, Y., Kurimoto, F. \& Nomura, K. (1980) Exp. Cell Res. 127, 143-157.

12. Aronsen, K. F., Ekeland, G., Kindmark, C. O. \& Laurell, C. B. (1972) Scand. J. Clin. Lab. Invest. (Suppl.) 29, 127-136.

13. Scheinman, J. I., Fish, A. J. \& Michael, A. F. (1978) Am. J. Pathol. $90,71-88$.

14. Hahn, E., Wick, G., Pencer, D. \& Timpl, R. (1980) Gut $21,63-71$.

15. Kahn, P. \& Shin, S. I. (1979) J. Cell Biol. 82, 1-16.

16. Reilly, J. T., McVerry, B. A. \& Mackie, M. J. (1981) J. Clin. Pathol. 36, 1377-1381.

17. Säba, T. M. \& Jaffe, E. A. (1980) Am. J. Mèd. 68, 577-594.

18. Mosher, D. F. (1975) J. Biol. Chem. 250, 6614-6621.

19. Tankum, J. W. \& Hynes, R. O: (1983) J. Biol. Chem. 258, $4641-4647$.

20. Glund, C., Dejgaard, A. \& Clemmensen, I. (1983) Scand J. Clin. Lab. Invest. 43, 533- 537.

21. Eriksen, H. O., Skjoldby, O., Kjersen, H., Selmer, J., Tranebjaerg, L. \& Clemmensen, I. (1984) Scand. J. Clin. Lab. Invest. 44, 135-142. methods, (tab. 2). However our data for fibronectin in ascites and segmental bronchoalveolar lavage are slightly higher but with lower S.D., a fact that is probably related to the greater sensitivity of the ELISA.

\section{Acknowledgement}

We wish to thank Ms. B. Rubio for her excellent technichal assistance in performing the fibronectin measurements, and Ms. I. Guillén who prepared pure fibronectin standards. We are also indebted to Drs. D. Carrasco, and $M$. Prieto from the Servicio de Digestivo, Departamento de Medicina Interna del Hospital $\mathrm{La} \mathrm{Fe}$ for providing the samples of ascites liquid, and to Dr. V. Marco from Servicio de Neumología, Departamento de Medicina Interna, Hospital $\mathrm{La} \mathrm{Fe}$ for the samples of segmental bronchoalveolar lavage. Dr. $J$. Vallés advised us in designing the experiments with hyperlipaemic sera. The economic assistance of the Fondo de Investigaciones Sanitarias (grants 41/82 and $972 / 83$ ) is acknowledged.

22. Laurell, C. B. (1972) Scand. J. Clin. Lab. Invest. (Suppl.) $29,21-37$.

23. Pott, G. \& Meyering, M. (1980) J. Clin. Chem. Clin. Biochem. 18, 893-895.

24. Ruoslahti, E., Vuento, M. \& Engvall, E. (1978) Biochim. Biophys. Acta 534, 210-218.

25. Ruoslahti, E., Hayman, E. G., Pierschbacher, M. \& Engvall, E. (1982) in Methods in Enzymology (Cunningham, L. W. \& Frederiksen, D. W., eds.), Vol. 82, pp. 803-831, Academic Press, New York.

26. Gómez-Lechón, M. J., Castell, J. V. (1985) Anal. Biochem. $145,1-8$.

27. Engvall, E. \& Ruoslahti, E. (1977) Int. J. Cancer 20,1-5.

28. Grabar, P. \& Williams, C. A. (1953) Biochim. Biophys. Acta 10, 194-199.

29. Nakane, P. K. \& Kawaoi, A. (1974) J. Histochem. Cytochem. 22, 1084-1091.

30. Eriksen, H. O., Clemmensen, I., Hansen, M. S. \& Ibsen, K. K. (1982) Scand. J. Clin. Lab. Invest. 42, $291-295$.

31. Bowen, M. \& Muller, T. (1983) J. Clin. Pathol. 36, $233-235$

32. Toy, P. T. \& Reid, M. (1984) J. Clin. Pathol. 37, 951-952.

33. Stathakis, N. E., Mosesson, M. W., Chen, A. B. \& Galanakis, D. K. (1978) Blood 51, $1211-1215$.

34. Matsuda, M., Yoshida, N., Aoki, N. \& Wakabayashi, Y. (1978) Ann. N. Y. Acad. Sci. 312, 74-92.

35. Pearlestein, E. \& Baez, L. (1981) Anal. Biochem. 116, 292-297.

36. Matsuda, M., Yamanaka, T. \& Matsuda, A. (1982) Clin. Chim. Acta 118, $191-195$.

37. Kawamura, K., Tanaka, M., Kamiyama, F., Higashino, K. \& Kishimoti, S. (1983) Clin. Chim. Acta 131, 101- 108.

38. Annoni, G., Cargnel, A., Onato, M. F., Marchesini, D., Dioguardi, F. S. \& Colombo, M. (1982) 17th EASL Meeting. Gotheburg (S). Abstract 101

39. Schölmerich, B., Volk, A., Köttgen, E., Ehlers, S. \& Gerok, W. (1984) Gastroenterology 87, 1160-1164.

40. Villiger, B., Broekelmann, T., Kelley, D., Heymach, G. V. \& McDonald, J. A. (1981) Amer. Rev. Respir. Dis. 124, 625-654.
Dr. J. V. Castell
Centro de Investigación
Hospital La Fe
Ministerio de Sanidad
Avda. de Campanar 21
E-46009 Valencia 
